\title{
RESEARCH PROGRESS ON THE TREATMENT OF LIVESTOCK AND POULTRY FECES CONTAINING HEAVY METAL RESIDUES BY PASSIVATOR
}

\author{
JiANG, H. F. ${ }^{1,2}-$ HU, X. F. ${ }^{1,2}-$ HUANG, X. K. ${ }^{1,2}-$ ZhANG, Y. J. ${ }^{1,2}$ - HUANG, F. C. ${ }^{1,2,3 *}-$ WEI, Y. M. ${ }^{3 *}$ \\ ${ }^{1}$ School of Mechanical Engineering, Guangxi University, Nanning 530004, China \\ ${ }^{2}$ Guangxi Key Laboratory of Petrochemical Resource Processing and Process Intensification \\ Technology, Guangxi University, Nanning 530004, China \\ ${ }^{3}$ Guangxi Livestock and Poultry Waste Resource Utilization Engineering Technology Center, \\ Nanning 530004, China \\ (phone: +86-132-7781-6948; fax: +86-132-7781-6948) \\ *Corresponding authors \\ e-mail: huangfuchuan@gxu.edu.cn; phone/fax: +86-139-7711-2910 \\ e-mail:dkywym@163.com; phone/fax:+86-139-0786-9497 \\ (Received 21 ${ }^{\text {st }}$ Jun 2018; accepted $31^{\text {st }}$ Aug 2018)
}

\begin{abstract}
In view of the current pollution of heavy metals in livestock and poultry in China, this paper discusses bioavailability of heavy metals and the classification of passivators, as well as different types passivators on characteristics of residual heavy metal passivation in livestock and poultry waste. On this basis, the research and application of physical, chemical and biological passivators are presented. The passivating effect of different passivators on heavy metals in livestock and poultry waste is introduced, which provides a technical reference for the application of passivator to the treatment of heavy metals in livestock and poultry waste.
\end{abstract}

Keywords: livestock wastes, passivator, heavy metal residues, bioavailability, sugarcane pulp

\section{Introduction}

With the rapid expansion of large-scale and intensive livestock and poultry production in China, the amount of livestock manure emissions has increased rapidly. According to relevant statistics: at the end of 2010, the total excrement of livestock and poultry excrement in China was about $22.35 \mathrm{t}$ (Geng et al., 2013). It is predicted that the total amount of livestock and poultry manure pollution will increase by $31 \%$ in 2020 (Wu et al., 2013). It is well known that heavy metals such as $\mathrm{Cu}, \mathrm{Zn}$, As and $\mathrm{Cr}$ are usually contained in livestock and poultry manure, which will cause serious pollution to the water, soil and atmospheric environment without treatment. A survey shows that 20 million hectares of cultivated land have been polluted by heavy metals, accounting for $1 / 6$ of the total area of the country's farmland (Lu et al., 2016). The amount of grain contaminated by heavy metals amounts to 12 million tons, resulted in a direct economic loss of more than 200 billion Yuan (Cai et al., 2014). The pollution caused by heavy metals in livestock and poultry waste has posed serious threat to the ecological environment and food safety of our country, and it has become one of the main factors restricting the development of green ecological agriculture in China.

Passivator is a kind of material that has adsorption, affinity and exchange metal ions. Its main function is to convert the heavy metal ions in the organic matter into fixed and stable insoluble form, reduce the bioavailability of heavy metals in the feces of 
livestock and poultry, and reduce environmental pollution. The related studies showed that the distribution coefficient of exchangeable state, carbonate binding state and iron manganese oxide binding state $\mathrm{Pb}, \mathrm{Cu}, \mathrm{Cr}$ and $\mathrm{As}$ in pig manure after composting was significantly decreased. Specific passivator reduced the activity of heavy metals and reduced the risk of heavy metals in livestock and poultry feces from contamination of soil and crops (Zheng et al., 2005). In this paper, the bioavailability of heavy metals, the types of heavy metal passivator in livestock and poultry manure and the new progress in the application of some passivator were introduced. On this basis, some suggestions and prospects were present to provide a technical reference for the subsequent application of passivator concerning the solutions to the problem of residual heavy metal in livestock and poultry manure.

\section{Bioavailability of heavy metals}

The researchers usually define the degree of bioavailability of heavy metals and the accumulation and toxicity of migration in the organism by referring to the bioavailability of heavy metals (Fig. 1). The research indicates that the bioavailability of heavy metals not only relates to the content of heavy metals, but also relates to their existing forms (Huang et al., 2010). According to the common sequential extraction method (Nemati et al., 2011; Elwell et al., 2001), the form of residual heavy metals in waste can be divided into water soluble state, organic binding state, exchangeable state, carbonate binding state, oxide bound state (iron manganese oxidation state) and residue state. Additionally, the bioavailability can be reduced in turn (Yang et al., 2010). Meng Jun used DPTA extract to explore the bioavailability of $\mathrm{Cu}, \mathrm{Mn}$ and $\mathrm{Zn}$ in pig manure. The results showed that the effective state of $\mathrm{Zn}$ and $\mathrm{Cu}$ reached $24.05-69.84 \%$ and $24.47-69.10 \%$, indicating that the biological availability of $\mathrm{Cu}$ and $\mathrm{Zn}$ in pig manure were higher than that in general; if not treated, pig manure would cause serious pollution to the environment (Meng et al., 2014). Dong Tongxi and other researchers explored the dynamic changes of the bioavailability of $\mathrm{Cu}, \mathrm{Zn}, \mathrm{Cd}$ and $\mathrm{Pb}$ in the organic manure of different livestock and poultry manure, and pointed out that the bioavailability of different heavy metals in the production of organic manure from different livestock and poultry manure was different (Dong et al., 2016). Zhang Yunqing and other researchers studied the difference of bioavailability of heavy metals in manure of different livestock and poultry and their dynamic changes over culture time by using biological pot experiment method. The results showed that the bioavailability of $\mathrm{Cu}, \mathrm{Zn}$ and $\mathrm{Cd}$ in livestock and poultry manure was significantly lower than that of heavy metals in the calcareous and acidic soil a few months after adding livestock and poultry manure (Zhang et al., 2015). Therefore, the bioavailability of heavy metals is an important indicator to measure the seriousness of heavy metal pollution. Reducing the bioavailability of heavy metals in livestock and poultry is one of the effective measures to reduce the pollution caused by heavy metals in livestock and poultry waste. The addition of specific quantities and types of passivator can greatly reduce the bioavailability of heavy metals in livestock manure.

\section{Classification of passivator}

Usually, passivators are classified into three types according to their mechanism and material properties. These include physical passivator, chemical passivator and biological passivator (Li et al., 2018). 


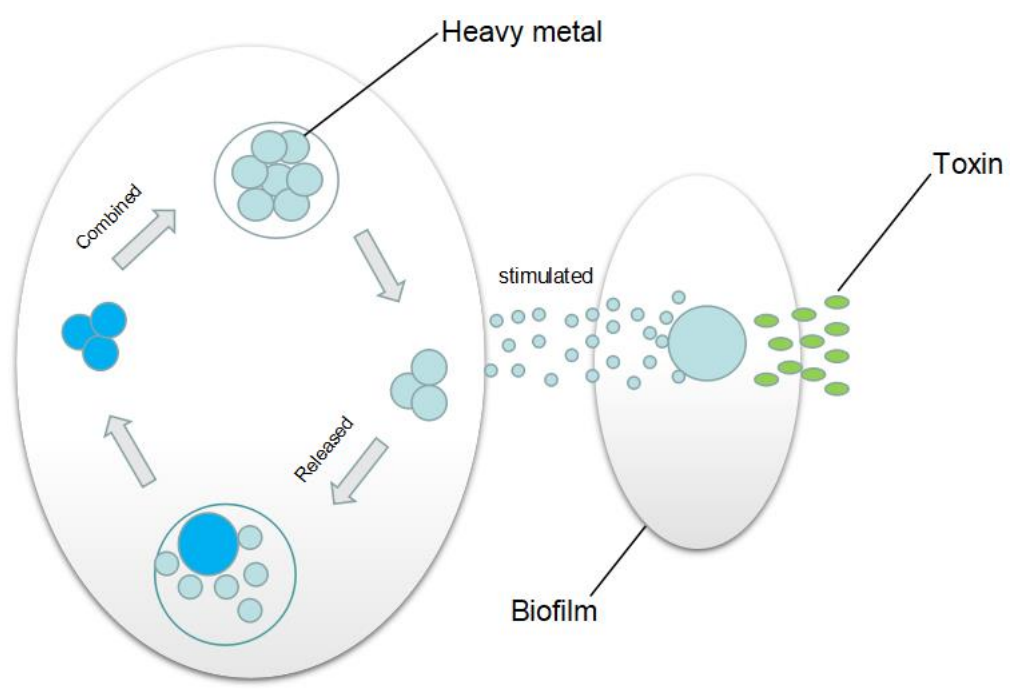

Figure 1. Schematic diagram of bioavailability

\section{Physical passivator}

In the process of organic fertilizer production, passivation means using a type of passivator to passivate heavy metals in the raw material of organic manure, as so to reduce the dissolution, transfer, bioavailability and absorption of all kinds of heavy metals (Laperche et al., 1997; Conder et al., 2001; Tang et al., 2003; Chen et al., 2006). Commonly used types of physical passivator (Fig. 2) include: dechonite, zeolite, activated carbon, sepiolite and quicklime (Li et al., 2014; Liu et al., 2017; Hou et al., 2014). Physical passivator is characterized by high porosity, large surface area, strong physical adsorption capacity and ion adsorption capacity, which can effectively reduce the biological activity of heavy metals. However, the passivation efficiency of physical passivator is not high because the passivation agent and organic fertilizer products are difficult to separate, which affects the fertilizing efficiency and quality of organic fertilizer.

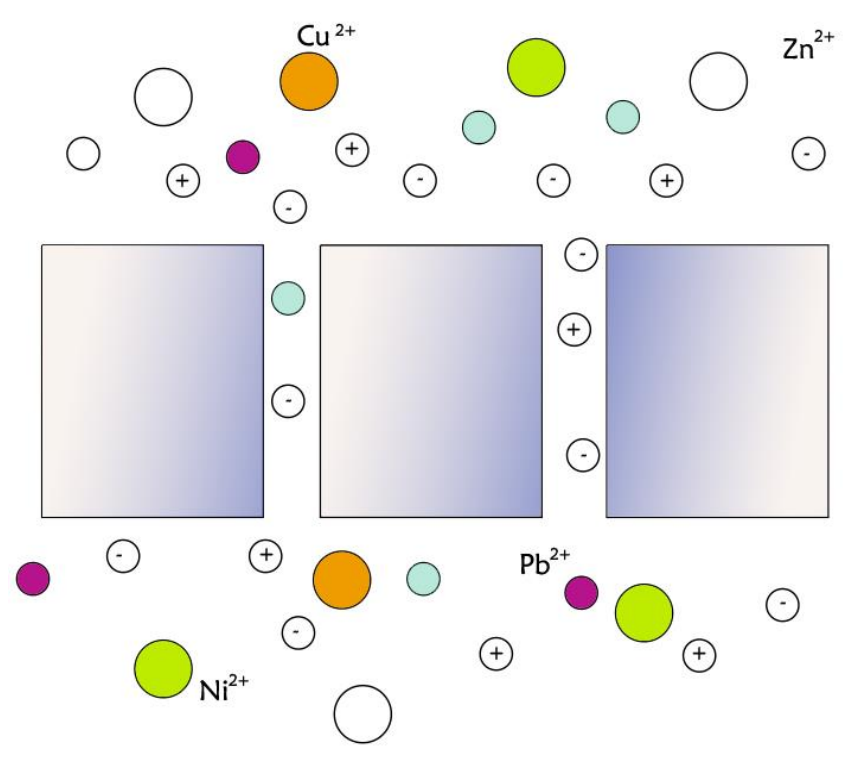

Figure 2. The adsorption mechanism of physical passivator 


\section{Chemical passivator}

Heavy metal ions are mainly treated by surfactants (Zhao et al., 2003), acidifiers (Yuan et al., 2006) and organic complexing agents (Zhang et al., 2006). Usually, they can change the $\mathrm{pH}$ value of livestock and poultry feces by complexation, ion exchange, precipitation. Chemical passivator change the occurrence forms of heavy metals in organic fertilizer and change the bioavailability and migration of heavy metals (Liang et al., 2012). (The mechanism is as shown in Fig. 3). Chemical passivator include calcium magnesium phosphate fertilizer (Xu., 2006), phosphate rock powder (Elouear et al., 2008), fly ash (Siddiqui et al., 2004) and so on. The deficiency of chemical passivator is that it is easy to cause secondary pollution to the soil environment (Mo et al., 2001), which limits the popularization and application of chemical passivator. At present, chemical passivator are rarely used in the treatment of livestock and poultry feces, mainly because chemical passivators can damage the ecological environment. In addition, the passivator can not be recycled or decomposed into harmless substances and the recovery efficiency is low.

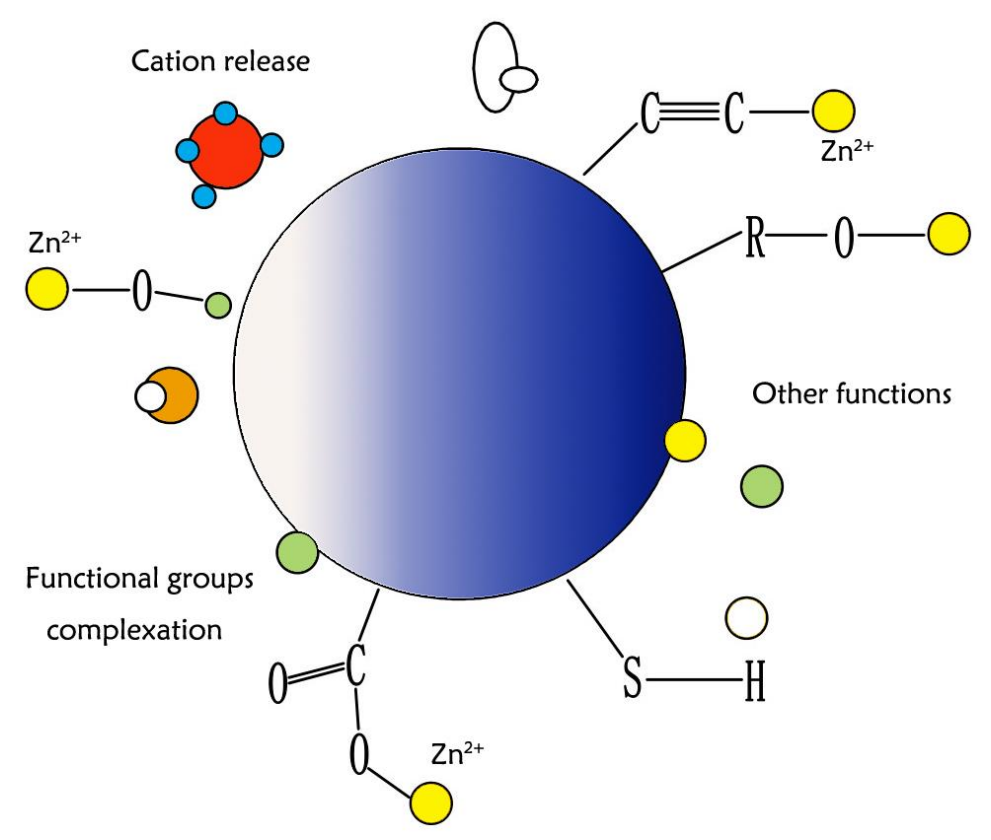

Figure 3. Schematic diagram of chemical passivation mechanism

\section{Biological passivator}

Biological passivators (Fig. 4) absorb the residual heavy metals in the waste and reduce the biological activity of heavy metals through microbial physiological action, and then form a new encapsulated biofilm and finally make it precipitate. Biological passivators mainly includes Phanerochaete chrysosporium (Huang et al., 2017), Chlorophyta (Anastopoulos et al., 2015), white rot fungus (Zhang et al., 2017), Bacillus (Wang et al., 2018) and compound biological agent (Pan et al., 2010). Studies have shown that some microbes or microbial agents such as green algae, white rot fungi and Bacillus can reduce heavy metals by absorption, encapsulation, precipitation, immobilization and covalent transformation of heavy metal ions in the environment (Pavel et al., 2011; Xue et al., 2012; Tian et al., 2013). In the production of organic 
fertilizer, biofiltration is the main microorganism technology ( $\mathrm{He}$ and $\mathrm{Hu}, 2011$ ). Although the efficiency of this method is high, but the cost is too high and the posttreatment is difficult. It is easy to cause secondary pollution. At present, it is still in the stage of laboratory research and its related practical engineering application technology is not mature.

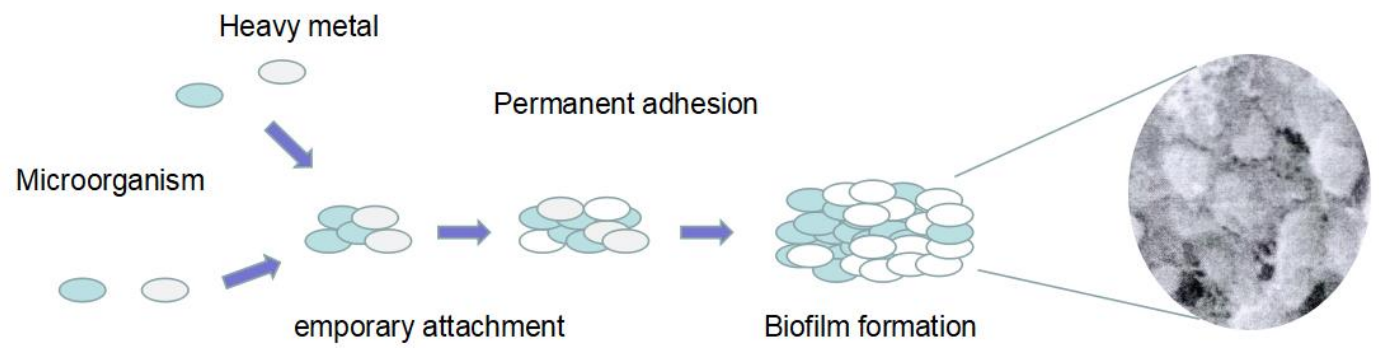

Figure 4. Microbiological affinity adsorption diagram

Any type of passivator has its own principle and characteristics. Table 1 summarizes and compares the above passivators.

Table 1. Comparison of heavy metal passivator for livestock wastes and other wastes

\begin{tabular}{|c|c|c|c|c|}
\hline Type of passivator & $\begin{array}{l}\text { Principle of } \\
\text { passivation }\end{array}$ & Common species & Advantages & Disadvantages \\
\hline Physical passivator & $\begin{array}{l}\text { Physical adsorption } \\
\text { of substances with } \\
\text { higher adsorption } \\
\text { capacity }\end{array}$ & $\begin{array}{c}\text { Activated carbon, } \\
\text { Zeolite, Sepiolite, } \\
\text { Bentonite, } \\
\text { Quicklime, etc. }\end{array}$ & $\begin{array}{l}\text { High porosity and } \\
\text { large specific } \\
\text { surface area }\end{array}$ & $\begin{array}{c}\text { Passivation } \\
\text { efficiency is low } \\
\text { and difficult to } \\
\text { separate }\end{array}$ \\
\hline Chemical passivator & $\begin{array}{c}\text { Regulating and } \\
\text { changing the } \\
\text { occurrence of heavy } \\
\text { metals in compost } \\
\text { by complexation, } \\
\text { precipitation and } \\
\text { ion exchange (Liang } \\
\text { et al., 2012) }\end{array}$ & $\begin{array}{c}\text { Calcium magnesium } \\
\text { phosphate fertilizer, } \\
\text { Phosphate rock } \\
\text { Powder, Fly ash }\end{array}$ & $\begin{array}{l}\text { Good availability } \\
\text { and mobility }\end{array}$ & $\begin{array}{c}\text { Secondary pollution } \\
\text { of the environment } \\
\text { limits the } \\
\text { development of } \\
\text { chemical } \\
\text { passivators }\end{array}$ \\
\hline $\begin{array}{l}\text { Biological } \\
\text { passivator }\end{array}$ & $\begin{array}{l}\text { Fusion, adsorption, } \\
\text { fixation, } \\
\text { precipitation, } \\
\text { covalent } \\
\text { transformation }\end{array}$ & $\begin{array}{c}\text { Phanerochaete } \\
\text { Chrysosporium, } \\
\text { Green algae, White } \\
\text { rot fungi, Bacillus } \\
\text { and Compound } \\
\text { microbial inoculants }\end{array}$ & $\begin{array}{c}\text { High efficiency } \\
\text { and large handling } \\
\text { capacity }\end{array}$ & $\begin{array}{l}\text { Difficult post- } \\
\text { treatment, } \\
\text { biological strain } \\
\text { contamination and } \\
\text { currently in the } \\
\text { experimental stage }\end{array}$ \\
\hline
\end{tabular}

\section{Application of passivation agent in the treatment of residual heavy metals in animal manure}

\section{Application of physical passivator}

Quicklime is a kind of traditional and effective acid soil improver, which can reduce soil $\mathrm{pH}$ value, reduce heavy metal activity in soil, supplement plant calcium and magnesium nutrition, increase crop yield and quality (Yu et al., 2014). Wong and Selvam pointed out that the addition of lime as passivator in sludge composting process 
could effectively reduce the bioavailability of heavy metals (Wong and Selvam, 2006). Cheng Yi and other scholars analyzed the content and speciation of heavy metals in sludge before and after adding quicklime by BCR extraction method (Cheng et al., 2012). The results showed that the heavy metals in sludge could be passivated by quicklime and the contents of unstable heavy metals in sludge were decreased. Therefore, in the process of producing organic manure from livestock and poultry manure, proper addition of quicklime can effectively reduce the bioavailability of heavy metals and reduce the content of bioavailability of heavy metals in livestock and poultry manure.

Among the natural minerals found at present, Zeolite has the largest specific surface area and the best adsorption capacity (Chen, 2001). Cheng Ting and other researchers found that the specific surface area of synthetic zeolite had great influence on the adsorption of heavy metal ions $\mathrm{Ni}, \mathrm{Pb}$ and $\mathrm{Cu}$ (Cheng et al., 2016). Li $\mathrm{Yi}$ and other researchers found that after the anaerobic fermentation of pig manure, the effective content of heavy metal $\mathrm{Zn}$ in the residue of non zeolite was $32.63 \%$, while the effective content of $\mathrm{Zn}$ in the addition of zeolite was $29.12 \%$. Therefore, zeolite addition can reduce the bioavailability of heavy metal $\mathrm{Zn}$ (Li et al., 2016).

Other physical passivators have also been studied for the treatment of residual heavy metals in livestock and poultry feces. Song Hefu and other researchers found that the outer surface of the small particles of sepiolite can form a hydrated oxide covering layer. Moreover, the electrical properties of the surface were negative, which is beneficial to the complexation or adsorption of heavy metal ions in the livestock and poultry manure (Song and Xia, 2000). Alvarez-Ayuso E and other scholars showed that when the amount of sepiolite was $4 \%$, the content of available $\mathrm{Zn}$ in contaminated soil could be reduced by more than $95 \%$ (Alvarez-Ayuso et al., 2003).

\section{Application of chemical passivator}

Calcium magnesium phosphate fertilizer contains a large amount of phosphorus, calcium, magnesium and other elements needed for crop growth. It is a commonly used phosphate fertilizer or acid soil sample improver, which can promote the growth and development of plants and enhance their resistance to stress (Zhang et al., 2012); it can also be used as a heavy metal passivator to effectively reduce the bioavailability of residual heavy metals in compost and soil (Wu et al., 2015; He, 2011). Qian Haiyan and other researchers carried out pot experiments to study the improvement effect of calcium magnesium phosphate and lime on crop soil contaminated by $\mathrm{Cu}$ and $\mathrm{Zn}$. The research shows that the growth of crops is basically not polluted by heavy metals in the soils with calcium magnesium phosphate and lime. Calcium magnesium phosphate can reduce the pollution of heavy metals to some extent. However, the phosphate fertilizer which is not completely absorbed can cause secondary pollution to the ecological environment (Li et al., 2017).

Phosphate mineral is a common phosphate mineral, and its main component is fluorapatite (chemical formula, Ca10(PO4)6F2). Phosphate mineral contains total phosphorus (phosphorus pentoxide) 10-35\%, in which the phosphorus of $3-5 \%$ is soluble in weak acid and can be absorbed and utilized by crops, but most of the other crops are difficult to absorb and use directly. It belongs to insoluble phosphate fertilizer. Its structure has many forms. Mineral phosphorus powder is not only a passivator with high ratio of performance to price, but also does not cause environmental damage (Scheckel et al., 2003). Liu Yu and other researchers used phosphate rock to study the 
adsorption of $\mathrm{Cd}^{2+}, \mathrm{Zn}^{2+}, \mathrm{Pb}^{2+}, \mathrm{Cu}^{2+}, \mathrm{Cr}^{2+}, \mathrm{Fe}^{2+}$ and $\mathrm{Hg}^{2+}$ in livestock and poultry manure. The results showed that phosphate rock powder has a good passivation effect on most heavy metal ions (Liu and Peng, 2001).

Other kinds of chemical passivators are also used in the production of organic fertilizer. Zhang Shuqing found that in the process of pig manure composting, $10 \%$ weathered coal was added to the experiment. In the experiment, the water soluble content of $\mathrm{Zn}, \mathrm{Cr}, \mathrm{Cu}$ and As decreased $6.17 \%, 4.17 \%$, and $1.83 \%$ respectively (Zhang et al., 2006). Weathered coal has passivation effect on water-soluble metal in pig manure organic fertilizer. Xi Yonghui and other researchers explored the adsorption ability of fly ash and bentonite to heavy metal ions $\mathrm{Ni}^{2+}, \mathrm{Pb}^{2+}, \mathrm{Cd}^{2+}$ and $\mathrm{Zn}^{2+}$. The results showed that the adsorption capacity of $\mathrm{Zn}^{2+}$ is equal to that of bentonite, and that of bentonite is lower than that of fly ash. However, with the increase of heavy metal content, the adsorption effect of fly ash and bentonite on heavy metal ion $\mathrm{Ni}^{2+}, \mathrm{Pb}^{2+}$, $\mathrm{Cd}^{2+}$ and $\mathrm{Zn}^{2+}$ is decreased ( $\mathrm{Xi}$ and Zhao, 2004).

\section{Application of biological passivator}

Phanerochaete chrysosporium is a kind of white rot fungus, which can be used to remove heavy metals (Mittar et al., 1992). Say and other showed that Phanerocephala sporophyllum had a certain adsorption ability to $\mathrm{Cd}, \mathrm{Pb}$, and $\mathrm{Cu}$, but it had the strongest adsorption ability to $\mathrm{Pb}$ (Ridyan et al., 1999). Under the optimum adsorption conditions, the maximum adsorption capacities of $\mathrm{Pb}, \mathrm{Cd}, \mathrm{Cu}$ were $27.79 \mathrm{mg} / \mathrm{g}, 85.86 \mathrm{mg} / \mathrm{g}$ and $26.55 \mathrm{mg} / \mathrm{g}$, respectively. In the process of sludge producing organic fertilizer, Wan Li $\mathrm{Li}$ added different proportion of compound microbial inoculants. The study showed that the compound microbial inoculum added $10 \%$ and the exchangeable state of $\mathrm{Zn}$ decreased by $17.7 \%$ (Wan, 2014). Zhou Shungui and other studies show that sludge biological leaching can effectively dissolve heavy metals in sludge by inoculating Thiobacillus ferrooxidans. After 4 10d biological leaching, the maximum removal rate of $\mathrm{Cu}, \mathrm{Cr}$ and $\mathrm{Zn}$ can reach $80 \%, 100 \%$, and 100\%, respectively (Zhou et al., 2003).

Heavy metals may stimulate the growth of anaerobic bacteria during the production of organic manure. It is usually beneficial to the reproduction and growth of cells. However, high concentrations of heavy metals in animal feces inhibited bacterial growth. In particular, copper, nickel, zinc, lead and other heavy metal ions are more toxic to bacteria, even if there are only trace amounts of digestive juice, they will have serious consequences (Zhang, 1996). Xu and Guo found: in order to reduce the toxicity of heavy metals. Heavy metals can be precipitated by organic or inorganic ligands to adsorb or chelate the residual heavy metals in animal feces (Xu et al., 2018; Guo et al., 2017).

\section{Passivation effects of different passivator on heavy metals}

Different types of passivator differ in passivation effects and removal rates. Table 2 shows the passivation effect of different passivator to heavy metal.

\section{Conclusions and prospects}

Due to the rapid development of livestock and poultry breeding industry, the environmental pollution caused by heavy metal residues in feces is becoming more and more serious. At present, the use of existing passivator can reduce the bioavailability of 
heavy metal residues in livestock and poultry feces to a certain extent and can reduce the pollution of heavy metals to the ecological environment. However, there are still some heavy metals in the excrement of livestock and poultry that exceed the standard seriously, which lead to the new ecological environment pollution. The types of passivator used at present also have the disadvantages which easily cause secondary pollution and high cost. Therefore, it is necessary to further study their characteristics in order to develop a variety of green, environmentally friendly and inexpensive passivator series. In this paper, some opinions and prospects for heavy metal residues in livestock and poultry feces are presented.

Table 2. passivation effect of different passivators on heavy metals in compost

\begin{tabular}{|c|c|c|c|c|c|c|c|c|c|c|c|}
\hline \multirow{2}{*}{$\begin{array}{c}\text { Types of } \\
\text { passivators }\end{array}$} & \multirow{2}{*}{$\begin{array}{c}\text { Compost } \\
\text { type }\end{array}$} & \multirow{2}{*}{ Passivator } & \multicolumn{7}{|c|}{ Passivation effect $(\%)$} & \multirow{2}{*}{ Methods } & \multirow{2}{*}{ References } \\
\hline & & & $\mathbf{C u}$ & Zn & $\mathbf{C r}$ & $\mathbf{P b}$ & Cd & $\mathbf{N i}$ & As & & \\
\hline \multirow{3}{*}{$\begin{array}{l}\text { Physical } \\
\text { passivator }\end{array}$} & \multirow[b]{2}{*}{$\begin{array}{l}\text { Pig } \\
\text { manure }\end{array}$} & Meerschaum & 84.9 & 71.2 & 53.8 & 76.2 & 79.3 & - & 89.4 & \multirow{2}{*}{\begin{tabular}{|c|} 
Plasma \\
emission \\
spectrometer \\
ICP
\end{tabular}} & \multirow[b]{2}{*}{ Liu, 2008} \\
\hline & & Zeolite & 71.0 & 61.6 & 62.9 & 76.3 & 71.0 & - & 79.2 & & \\
\hline & Mud & $33 \%$ shell & 62.88 & 78.74 & 98.3 & 98.9 & 0.08 & 58.45 & - & \begin{tabular}{|c|} 
BCR \\
extraction \\
method
\end{tabular} & $\begin{array}{l}\text { Cheng et } \\
\text { al., } 2012\end{array}$ \\
\hline \multirow{5}{*}{$\begin{array}{l}\text { Chemical } \\
\text { passivator }\end{array}$} & \multirow{4}{*}{$\begin{array}{l}\text { Pig } \\
\text { manure }\end{array}$} & $\begin{array}{l}\text { Ground } \\
\text { phosphate } \\
\text { rock }\end{array}$ & 48.0 & 51.3 & 53.3 & 63.1 & 51.0 & - & 54.0 & \multirow{2}{*}{$\begin{array}{c}\text { Plasma } \\
\text { emission } \\
\text { spectrometer } \\
\text { ICP }\end{array}$} & \multirow[b]{2}{*}{ Liu, 2008} \\
\hline & & $\begin{array}{c}\text { Calcium } \\
\text { magnesium } \\
\text { phosphate }\end{array}$ & 51.0 & 71.6 & 53.7 & 62.2 & 80.7 & - & 75.3 & & \\
\hline & & $\begin{array}{c}10 \% \\
\text { weathered } \\
\text { coal }\end{array}$ & 69.03 & 84.10 & 55.76 & - & - & - & 27.5 & $\begin{array}{c}\text { Heavy metal } \\
\text { passivation } \\
\text { experiment }\end{array}$ & $\begin{array}{l}\text { Zhang et } \\
\text { al., } 2006\end{array}$ \\
\hline & & Fly ash & - & 88.40 & - & 86.08 & 89.60 & 66.20 & - & $\begin{array}{c}\text { Dynamic } \\
\text { adsorption } \\
\text { test }\end{array}$ & $\begin{array}{l}\text { Xi et al., } \\
2004\end{array}$ \\
\hline & $\begin{array}{l}\text { Chickn } \\
\text { manure }\end{array}$ & \begin{tabular}{|c|}
$10 \%$ \\
Efflorescent \\
coal \\
\end{tabular} & 76.91 & 79.34 & 63.93 & - & - & - & 24.98 & $\begin{array}{c}\text { Heavy metal } \\
\text { passivation } \\
\text { experiment }\end{array}$ & $\begin{array}{l}\text { Zhang et } \\
\text { al., } 2006\end{array}$ \\
\hline \multirow{2}{*}{$\begin{array}{l}\text { Biological } \\
\text { passivator }\end{array}$} & \multirow[b]{2}{*}{ Mud } & $\begin{array}{l}\text { Thiobacillus } \\
\text { ferrooxidans }\end{array}$ & 80 & 100 & 100 & - & - & - & - & \multirow{2}{*}{$\begin{array}{c}\text { Bioleaching } \\
\text { method }\end{array}$} & \begin{tabular}{|c} 
Zhou et al., \\
2003 \\
\end{tabular} \\
\hline & & \begin{tabular}{|l|} 
Thiobacillus \\
ferrooxidans \\
$+4 \mathrm{~g} / \mathrm{L} \mathrm{Fe}^{2+}$
\end{tabular} & 92 & 83 & 55 & 16 & - & 54 & - & & $\begin{array}{l}\text { Zhou et al., } \\
2002\end{array}$ \\
\hline
\end{tabular}

1) Physical, chemical and biological passivator have their own characteristics. The first two types of passivator have been used in the basic mature technology, but their comprehensive performance is not very well, it is necessary to further study the characteristics of the passivator to reduce its shortcomings. However, biological passivator has high treatment efficiency, biological strain pollution and high cost of treatment. At present, this type of passivator is still in the experimental stage. In the future, it is necessary to further improve the technology and solve the related practical 
engineering problems. In particular, a series of complex biological passivators with low cost, high efficiency and no pollution have been developed by using gene technology.

2) At present, many scholars are studying the compound passivator and its performance is better than that of single passivator. In the future, big data can be used as the supporting platform and advanced mathematical methods can be used for the experimental study of the passivating agent. Compound passivator can solve the technical bottleneck of engineering so that it can be popularized and applied.

3) We should make full use of agricultural wastes rich in resources. For example, sugarcane pulp is a kind of renewable biomass material from sugarcane waste. The treatment of residual heavy metals in feces by modified sugarcane pulp can effectively improve the recovery efficiency of resources. The modified sugarcane pulp was mixed with a certain amount of quicklime and calcium magnesium phosphate fertilizer to form a compound passivator, which is more efficient than a single treatment of heavy metals in feces and greatly reduces the biological activity of heavy metals in the feces. As a compound passivator, the modified sugarcane pulp provides a technical reference for the subsequent treatment of heavy metals. The types of passivators have a great development prospect.

Acknowledgements. This study was supported by the Ministry of Science and Technology for the National Spark Program (NO.2015GA790003) and Project of Guangxi Key Laboratory of Petrochemical Resource Processing and Process Intensification Technology (NO.2017Z009).

\section{REFERENCES}

[1] Alvarez-Ayuso, E., Garcia-Sánchez, A. (2003): Sepiolite as a feasible soil additive for the immobilization of cadmium and zinc. - Science of the Total Environment 305(1-3): 1-12.

[2] Anastopoulos, I., Kyzas, G. Z. (2015): Progress in batch biosorption of heavy metals onto algae. - Journal of Molecular Liquids 209: 77-86.

[3] Cai, M. F., Li, K. M., Xie, D. P., Wu, R. R. (2014): Study on the present situation and Countermeasures of heavy metal pollution in cultivated soil in China. - Environmental Science and Technology 37(S2): 223-230 (in Chinese).

[4] Chen, G. A. (2001): Experimental study on the treatment of heavy metal ion wastewater by zeolite. - Mineral Protection and Utilization 6: 17-19 (in Chinese).

[5] Chen, S. B., Zhu, Y. G., Ma, Y. B., McKay, G. (2006): Effect of bone char application on $\mathrm{Pb}$ bioavailability in a Pb-contaminated soil. - Environmental Pollution 139(3): 433-439.

[6] Cheng, T., Chen, C., Gan, F. Q. et al. (2016): Adsorption properties of synthetic zeolite on heavy metal ions $\mathrm{Ni} \sim(2+), \mathrm{Pb} \sim(2+), \mathrm{Cu} \sim(2+)$. - Hubei Agricultural Science 55(24): 6413-6417 (in Chinese).

[7] Cheng, Y., Huang, J. M., Zhou, B. M. et al. (2012): Application of quicklime in heavy metal passivation of sludge. - Environmental Engineering S2: 325-326 (in Chinese).

[8] Conder, J. M., Lanno, R. P., Basta, N. T. (2001): Assessment of metal availability in smelter soil using earthworms and chemical extractions. - Journal of Environmental Quality 30(4): 1231-1237.

[9] Dong, T. X., Zhang, T., Li, Y. et al. (2016): The dynamic changes of the bioavailability of heavy metals in the organic manure of livestock and poultry in paddy soil. - Journal of Environmental Science 36(2): 621-629 (in Chinese).

[10] Elouear, Z., Bouzid, J., Boujelben, N. et al. (2008): Heavy metal removal from aqueous solutions by activated phosphate rock. - Journal of Hazardous Materials 156(1-3): 412420 . 
[11] Elwell, D. L., Keener, H. M., Wiles, M. C., Borger, D. C., Willett, L. B. (2001): Odorous emissions and odor control in composting swine manure/sawdust mixes using continuous and intermittent aeration. - Transactions of the ASAE 44(5): 1307.

[12] Geng, W., Hu, L., Cui, J. Y. et al. (2013): Study on the energy potential and total amount control of regional livestock and poultry manure in China. - Journal of Agricultural Engineering 291: 171-179 (in Chinese).

[13] Guo, J., Kang, Y., Feng, Y. (2017): Bioassessment of heavy metal toxicity and enhancement of heavy metal removal by sulfate-reducing bacteria in the presence of zero valent iron. - Journal of Environmental Management 203(Pt 1): 278.

[14] He, G., Hu, Q. (2011): Advances in bioleaching technology for heavy metals in municipal solid waste compost. - Anhui Chemical Industry 37(4): 66-69 (in Chinese).

[15] He, Z. M. (2011): the effects of passivating agents on transformation and bioavailability of heavy metals in pig manure compost. - Hunan Agricultural University (in Chinese).

[16] Hou, Q., Zhao, L. X., Shen, Y. J., Meng, H. B., Wang, F., Cheng, H. S. (2014): the source of blue sky. Effects of different conditioners on the form of heavy metals $\mathrm{Cu}, \mathrm{Zn}$, and $\mathrm{Cd}$ in pig manure compost. - Journal of Soil and Water Conservation 28(05): 275-279 (in Chinese).

[17] Huang, C., Zeng, G., Huang, D. et al. (2017): Effect of Phanerochaete chrysosporium, inoculation on bacterial community and metal stabilization in lead-contaminated agricultural waste composting. - Bioresource Technology 243: 294.

[18] Huang, Y. Y., Chen, G. F., Liu, B., Su, L. R. (2010): Research progress of heavy metal content, form and transformation in livestock manure. - Guangxi Agricultural Sciences 41(08): 807-809 (in Chinese).

[19] Laperche, V., Logan, T. J., Pranitha, G. A. et al. (1997): Effect of Apatite Amendments on Plant Uptake of Lead from Contaminated Soil. - Environmental Science \& Technology 31(10): 2745-2753.

[20] Li, Q. H., Yang, W. T., Zou, J. L. et al. (2017): Effect of calcium magnesium phosphate fertilizer on soil $\mathrm{Cd}$ bioavailability and $\mathrm{Cd}$ content in brown rice. - Journal of Environmental Science 37(6): 2322-2330 (in Chinese).

[21] Li, R., Zhao, L. X., Meng, H. B et al. (2018): Research progress on heavy metal passivation in organic waste composting process. - Chinese Agricultural Science and Technology Bulletin 20(1): 121-129 (in Chinese).

[22] Li, R. H., Zhang, G. J., Wang, Q., Zhang, Z. Q., Mao, H. (2014): Effects of adding minerals on the degradation of organic matter in aerobic composting of pig manure. Journal of Agricultural Machinery 45(06): 190-198+316 (in Chinese).

[23] Li, Y., Liu, Y. J., Feng, Y. Y. et al. (2016): Effects of zeolite on biogas fermentation characteristics of pig manure and the effect of heavy metal $\mathrm{Zn}$ in biogas slurry and biogas slurry. - Renewable Energy 34(6): 943-948.

[24] Liang, Y., Wang, X. C., Cao, X. D. (2012): Research progress on the remediation of heavy metal contaminated soil based on phosphate, carbonate and silicate materials. Environmental Chemistry 31(01): 16-25 (in Chinese).

[25] Liu, H. R. (2008): Study on Heavy Metal Passivation Technology in Pig Manure Composting. - Hunan Agricultural University, Changsha (in Chinese).

[26] Liu, X. Y., Shen, G. X., Qian, X. Y., Tang, Z. Z., Shu, Y. J., Yu, S. F. (2017): Different passivating agents on the passivation of heavy metal copper and zinc in organic manure of livestock and poultry by different passivating agents. - Jiangsu Agricultural Science 45(13): 209-213 (in Chinese).

[27] Liu, Y., Peng, M. S. (2001): Application of apatite in wastewater treatment. - Journal of Safety and Environment 1(1): 9-12 (in Chinese).

[28] Lu, Z. X. (2016): Current situation of heavy metal pollution in China's grain and its prevention and control measures. - Grain Technology and Economy 41(06): 6-11+53 (in Chinese). 
[29] Meng, J. (2014): Changes of Heavy Metals in Pig Manure during Composting and Pyrolysis and Their Application. - Zhejiang University, Hangzhou (in Chinese).

[30] Mittar, D., Khanna, P. K., Marwaha, S. S., Kennedy, J. F. (1992): Biobleaching of pulp and paper mill effluents by Phanerochaete chrysosporium. - Journal of Chemical Technology \& Biotechnology 53(1): 81-92.

[31] Mo, F., Cai, Q. Y., Wu, Q. T. et al. (2001): Research progress on the reduction of heavy metal content in municipal sludge by microbiological methods. - Application and Environmental Biology 7(5): 511-515 (in Chinese).

[32] Nemati, K., Bakar, N. K. A., Abas, M. R., Sobhanzadeh, E. (2011): Speciation of heavy metals by modified BCR sequential extraction procedure in different depths of sediments from Sungai Buloh, Selangor, Malaysia. - Journal of Hazardous Materials 192(1): 402410.

[33] Pan, S. Q., Sun, X. F., Zhong, H. F. et al. (2010): Effect of composite microbial inoculants on composting of municipal sludge. - Journal of Tropical Crops 31(1): 93-97 (in Chinese).

[34] Pavel, K., Martina, M., Tomas, M. (2011): Microbial Biosorption of Metals. - Springer, Netherlands.

[35] Ridyan, S., Adil, D. (1999): Biosorption of Cadmium ( II ), Lead ( II ) and Copper ( II ) with the Filamentous Fungus Phanerochaete Chrysosporium. - Bioresearch Technology 70: 95-104.

[36] Scheckel, K. G., Impellitteri, C. A., Ryan, J. A., McEvoy, T. (2003): Assessment of a sequential extraction procedure for perturbed lead-contaminated samples with and without phosphorus amendments. - Environmental Science \& Technology 37(9): 18921898.

[37] Siddiqui, S., Ahmad, A., Hayat, S. (2004): The fly ash influenced the heavy metal status of the soil and the seeds of sunflower. A case study. - Journal of Environmental Biology 25(1): 59.

[38] Song, H. F., Xia, C. B. (2000): Adsorption of natural zeolite on Pb (II) and Ni (II) ions. Mineral and Geology 14(4): 276-278 (in Chinese).

[39] Tang, X. Y., Zhu, Y. G., Chen, S. B. (2003): In vitro method to assess the bioavailability of $\mathrm{Pb}$ contaminated soil to human body. - Environmental Chemistry 22(5): 503-506 (in Chinese).

[40] Tian, W., Liu, M. Q., Xi, Y. G. (2013): Effect of microbial inoculants on the process of rapid composting with pig manure and letinous edodes residue as raw materials. - Soviet Agricultural Science 41(6): 301-304 (in Chinese).

[41] Wan, L. L. (2014): Effect of microbial inoculation on municipal sludge composting process. - Master's Thesis, Central South University, Changsha (in Chinese).

[42] Wang, Q., Zhang, W. J., He, L. Y. et al. (2018): Increased biomass and quality and reduced heavy metal accumulation of edible tissues of vegetables in the presence of Cdtolerant and immobilizing Bacillus megaterium H3. - Ecotoxicol Environ Saf 148: 269.

[43] Wong, J.W.C., Selvam, A. (2006): Speciation of heavy metals during co-composting of sewage sludgewith lime. - Chemosphere 63(6): 980-986.

[44] Wu, H. G., Liao, S. P., Jing, Y. et al. (2013): Analysis of Regional differences and Development trend of Animal manure pollution in China. - Environmental Science 34(7): 2766-2774 (in Chinese).

[45] Wu, W. C., Chen, X. B., Liu, X. W., Song, Q. M., Li, Y. B., Cai, X. D. (2015): Study on the difference of the effect of organic and inorganic fertilizer on the remediation of heavy metal contaminated paddy soil. - Journal of Agricultural Environmental Science 34(10): 1928-1935 (in Chinese).

[46] Xi, Y. H., Zhao, H. (2004): Adsorption of Ni2+, $\mathrm{Zn} 2+, \mathrm{Cd} 2+$ and $\mathrm{Pb} 2+$ by fly ash and bentonite. - Comprehensive Utilization of Fly Ash 3: 3-7 (in Chinese). 
[47] Xu, X. C. (2006): Development prospect of calcium magnesium phosphate fertilizer. Phosphate Fertilizer and Compound Fertilizer 21(3): 17-22.

[48] Xu, Y., Seshadri, B., Sarkar, B. et al. (2018): Biochar modulates heavy metal toxicity and improves microbial carbon use efficiency in soil. - Science of the Total Environment 621: 148-159.

[49] Xue, H. et al. (2012): Research progress of microbial remediation technology in heavy metal pollution control. - Chinese Agronomy Bulletin 28(11): 266-271 (in Chinese).

[50] Yang, H. M. (2010): Removal of Heavy Metals from Livestock Manure. - China University of Mining and Technology, Beijing (in Chinese).

[51] Yu, T. Y., Sun, X. S., Shi, C. G. et al. (2014): Research progress on soil acidification hazards and control technology. - Journal of Ecology 33(11): 3137-3143 (in Chinese).

[52] Yuan, H. S., Liu, Y. G., Li, X. et al. (2006): Removal efficiency of heavy metals in acidified sludge under electrodynamic action. - Environmental Sanitation Engineering 14(2): 5-8 (in Chinese).

[53] Zhang, C., Xu, Y., Zhao, M. et al. (2017): Influence of inoculating white-rot fungi on organic matter transformations and mobility of heavy metals in sewage sludge based composting. - Journal of Hazardous Materials 163-168.

[54] Zhang, D., Wang J., Pan, X. (2006): Cadmium sorption by EPSs produced by anaerobic sludge under sulfate-reducing conditions. - Journal of Hazardous Materials 138(3): 58993.

[55] Zhang, M. K., Tang, H. J., Chang, Y. C. (2012): Effect of different modifiers on reducing water soluble heavy metals in soil of mining area and its long-acting. - Soil and Water Conservation Journal 26(5): 144-148 (in Chinese).

[56] Zhang, S. Q., Zhang, F. D., Liu, X. M. et al. (2006): The effect of high temperature compost on antibiotic degradation and heavy metal passivation in livestock and poultry manure. - Chinese Agricultural Science 39(2): 337-343.

[57] Zhang, X. H. (1996): Wastewater Anaerobic Biological Treatment Engineering. - China Environmental Science Press, Beijing (in Chinese).

[58] Zhang, Y. Q., Zhang, T., Li, Y. et al. (2015): The dynamic changes of bioavailability of heavy metals in organic manure of livestock and poultry in different farmland. - Journal of Agricultural Environmental Science 34 (1): 87-96 (in Chinese).

[59] Zhao, G. X., Zhu, B. Y. (2003): Principles of surface active agents. - Daily Chemical Industry Information 17: 16-16 (in Chinese).

[60] Zheng, G. D., Chen, T. B., Gao, D. et al. (2005): Effects of aerobic and high temperature composting on the morphology of heavy metals in pig manure. - Environmental Science in China 25(1): 6-9 (in Chinese).

[61] Zhou, S. G., Zhou, L. X., Huang, H. Z. (2002): Application of bioleaching technology to remove heavy metals from sludge. - Acta Zoologica Sinica 22(1): 125-133 (in Chinese).

[62] Zhou, S. G., Wang, S. M., Yu, S. P. et al. (2003): Isolation and application of Thiobacillus ferrooxidans in sludge. - Environmental Science 24(3): 56-60 (in Chinese). 